\title{
DAMPAK MODEL KEPEMIMPINAN TERHADAP KINERJA PEGAWAI
}

\author{
RAHMAT LAAN ${ }^{1}$, ABDUL MALIK HASYIM ${ }^{2}$ \\ ${ }^{1 \& 2}$ Staf Pengajar Fakultas Ekonomi Univ. Muhammadiyah Kupang
}

\begin{abstract}
ABSTRAK
Penelitian ini bertujuan untuk menganalisis dampak model kepemimpinan transaksional dan transformasional terhadap kinerja pegawai birokrasi di Kabupaten Alor. Sampel penelitian sebanyak 182 PNS yang ditentukan dengan teknik dua tahap acak terstratifikasi tidak proporsional. Instrumen utama penelitin adalah kuesioner. Data penelitian dianalisis dengan model regresi berganda. Hasil penelitian menunjukkan bahwa kepemimpinan transaksional dan transformasional baik secara parsial maupun simultan berpengaruh signifikan terhadap kinerja pegawai. Kepemimpinan transaksional lebih menonjol dirasakan oleh pegawai setelah lebih dari satu dasawarsa reformasi birokrasi digulirkan, namun kepemimpinan transformasional mempunyai pengaruh lebih besar terhadap kinerja pegawai.
\end{abstract}

\section{Kata Kunci: Model Kepemimpinan, Kinerja Pegawai}

\section{PENDAHULUAN}

Salah satu tujuan reformasi biokrasi adalah memperbaiki dan meningkatkan kinerja pelayanan publik. Tujuan ini akan tercapai manakala tugastugas pelayanan publik dilakukan oleh pegawai birokrasi (PNS) yang berkinerja baik. Di sisi lain, kinerja PNS di Indonesia masih cukup rendah (Dwiyanto, dkk, 2002; Suryanto, dkk, 2008). Hal yang sama terjadi di Kabupaten Alor.

Sejumlah faktor diyakini mempengaruhi kinerja pegawai. Studi Kilmann (1996) tentang Beyond the Quicks Fix, Managing Five Tracks to Organisasional Success menemukan tendensi bahwa untuk menciptakan dan mempertahankan keberhasilan organisasi perlu diperhatikan lima faktor yakni (1) budaya organisasi, (2) keterampilan (gaya) kepemimpinan, pengembangan tim, (4) strategi-struktur, (5) sistem imbalan. Studi Pfeffer (1996) tentang Competitive Advantage Through People mendeteksi bahwa sumber daya manusia, budaya organisasi dan gaya kepemimpinan, kini semakin penting, sebagai penyumbang kinerja. Berikut studi Paracha, dkk (2012) tentang Impact of Leadership Style (Transformational \& Transactional Leadership) On Employee Performance \& Mediating Role of Job Satisfaction Study of Private School (Educator) In Pakistan menemukan bahwa gaya kepemimpinan transakional dan transformasional berhubungan positif signifikan dengan kinerja pegawai, walaupun kepemimpinn transaksional lebih signifikan dari kepemimpinan transformasional.

Penelitian ini akan menelaah model kepemimpinan (Kilmann, 1996; Pfeffer, 1996; Paracha, dkk, 2012) sebagai determinan kinerja pegawai negeri sipil yang bekerja di Kabupaten Alor. Ada sebuah harapan bahwa setelah reformasi, birokrasi seharusnya memiliki kepemimpinan yang mampu meningkatkan kesadara bawahan terhadap nilai, hasil usaha, pentingnya penyelesaian tugas, makna bekerja, tujuan moral kerja, dan memperhatikan kebutuhan pegawai melalui kewenangan dan pengaruh yang dimilikinya untuk bersama-sama mencapai tujuan organisasi. Namun, kita masih melihat kepemimpinan birokrasi menuntut loyalitas total dari anak-buahnya, mengembangkan sistem nepotisme (KKN), berorientasi pada politik kekuasaan, tidak ada pembagian kewenangan dalam pengambilan keputusan, komunikasi topdown, tercipta formalitas hubungan antara atasan dan bawahan yang berlebihan, dan lain-lain.

Kepemimpinan yang demikian, tidak saja menyebabkan rendahnya kinerja aparat birokrasi, tetapi juga sangat tidak kondusif bagi harapan masyarakat akan sebuah kepemimpinan yang mampu merespon berbagai tuntutan perubahan dan dinamika masyarakat yang bergerak cepat. Pertanyaannya, setelah lebih dari satu dasawarsa reformasi, apakah birokrasi kita sudah memiliki kepemimpinan seperti yang diharapkan. Untuk itu penelitian ini akan memotretnya dengan menggunakan konsep kepemimpinan transaksional dan transformasional (Burns, 1978).

\section{KAJIAN PUSTAKA}

\section{Kepemimpinan Transaksional}

Burns (1978) menjelaskan kepemimpinan transaksional sebagai hubungan pertukaran antara pemimpin dan pengikut. 
Fokus utama pemimpin transaksional adalah penjelasan peran bawahan dan pemimpin untuk mengetahui apa yang dibutuhkan pegawai dalam mencapai tujuan organisasi. Hellriegel dan Slocum (2006) menjelaskan bahwa kepemimpinan transaksional berdasarkan pada tiga komponen utama : contingent rewards, management by exception active, management by exception passive. Pertama, contingent reward. Contingent reward mengisyaratkan bahwa tersedia reward bagi bawahan. Ini merupakan bentuk pertukaran aktif dan positif antara pemimpin dan bawahan. Artinya bawahan yang mampu memperlihatkan prestasi memuaskan harus juga mendapatkan reward yang memuaskan. Reward tersebut tidak hanya tersedia dalam bentuk material tetapi juga berupa pujian, pengakuan, promosi, dan ucapan selamat. Kedua, management by exception-active. Management by exception-active mengisyaratkan kepemimpinan yang menekankan sejumlah aturan untuk mengawasi bawahan. Tipe kepemimpinan ini diterapkan dengan tujuan supaya bawahan terhindar dari berbagai kesalahan dan kegagalan. Ketiga, management by exception-pasive. Management by exception-pasive menekankan adanya kepercayaan dari pemimpin terhadap kemampuan bawahan. Kesempatan diberikan kepada bawahan untuk bekerja secara mandiri. Pimpinan akan segera bertindak bila diketahui terjadi problem yang memungkinkan bawahan mengalami kegagalan menyelesaikan pekerjaannya. Tujuannya menjaga standard dan mutu kerja yang ingin dicapai. Bentuk intervensi berupa memberikan informasi tentang apa yang terjadi, bagaimana melakukan tindakan perbaikan, dan bahkan tindakan memberhentikan bawahan dari tugasnya. Secara singkat bahwa kepemimpinan transaksional menyediakan benefit untuk pencapaian tujuan sedangkan hukuman bila tidak mencapai target.

\section{Kepemimpinan Transformasional}

Burns menjelaskan bahwa pemimpin transformasional memiliki kualitas moral yang lebih dan pemimpin memperhatikan kepentingan yang lebih besar di atas kepentingan kelompok. Avolio dan Bass (1994) mengklasifikasi skiil kepemimpinan dalam 4 I mencakup: idealized influence, inspirational motivation, intelektual stimulation, dan individualized consideration. Teori kepemimpinan transformasional
April 2017, Vol. 2, No. 3

ISSN: $1245-6578$

mengemukakan kekuasaan pemimpin memotivasi bawahan untuk mencapai lebih dari yang direncanakan oleh bawahan (Krishnan, 2004). Kemampuan manajerial adalah kemampuan lain dari kepemimpinan tranfoemasional yang juga mendasar bagi pemimpin. Kepemimpinan transformasional tidak dapat secara efektif diimplementasikan tanpa beberapa atribut utama kepemimpinan seperti : creatifitas, orientasi tim, dan penghargaan, wewenang pengajaran, tanggung jawab dan pengakuan (Perry, 1996). Kualitas elemen-elemen kepemimpinan transformasional adalah dasar bagi keberhasilan manajemen (Simic, 1998).

\section{Kinerja}

Higgins (1984) mengidentifikasi kinerja sebagai hasil kerja yang dapat dicapai oleh seseorang atau sekelompok orang dalam suatu organisasi, sesuai wewenang dan tanggung jawab masing-masing dalam rangka mencapai tujuan organisasi secara legal, tidak melanggar hukum dan sesuai moral maupun etika. Untuk mengetahui kinerja seorang pegawai dalam melaksanakan tugas, organisasi melaksanakan apa yang disebut sebagai penilaian kinerja/performance appraisal (Bernardin \& Rusel, 1993; Rivai \& Sagala, 2009). Penilaian kinerja harus memberikan gambaran yang akurat dari kinerja seorang pegawai (Desler, 1997; Rivai \& Sagala, 2009). Untuk itu diperlukan faktor-faktor penentu kinerja seorang pegawai yaitu . kuantitas pekerjaan, kualitas pekerjaan, ketepatan waktu, pengetahuan tentang pekerjaan, keterampilan, kemampuan mengatur pekerjaan, kerja sama, komunikasi, inisiatif dan kreatifitas.(Mondy, Siharplin, Flipo, 1995; Furtwengler, 2002; Bernadin \& Russel, 1993; Rafianto, 1986).

\section{Penelitian Terdahulu dan Pengembangan}

\section{Hipotesis}

Penelitian yang dilakukan oleh Paracha, dkk (2012) berjudul Impact of Leadership Style (Transformational \& Transactional Leadership) On Employee Performance \& Mediating Role of Job Satisfaction Study of Private School (Educator) In Pakistan. Dengan menggunakan analisis korelasi dan regresi, hasil penelitian menunjukkan bahwa gaya kepemimpinan transakional dan transformasional berhubungan positif signifikan dengan kinerja pegawai, walaupun kepemimpinn transaksional lebih signifikan 
dari transformasional. Temuan penting lainnya adalah tidak ada peran mediasi dari kepuasan kerja antara kepemimpinan transaksional dengan kinerja. Tetapi kepuasan kerja memediasi antara kepemimpinan transformasional dengan kinerja pegawai.

Penelitian yang dilakukan oleh Pradeep dan Prabhu (2011) berjudul The Relationship between Effective Leadership and Employee Performance. Penelitian ini memfokuskan diri pada model kepemimpinan transaksional, transformasuonal dan laissez-faire, dan hubungan antara gaya-gaya kepemimpinan tersebut dengan kinerja karyawan. Hasil yang disarankan adalah bahwa pemimpin harus memiliki kemampuan untuk menarik/mempengruhi bawahan mereka, dapat menentukan standar kinerja yang jelas dan melakukn peran terbaik kepada bawahan. Bawahan mengharapkan bahwa prestasi merek harus diakui dan diberi imbalan baik moneter maupun non moneter. Skor Gareett menunjukan bahwa preferensi manajer tingkat menengah dan bawahan merekomendasikan gaya kepemimpinan transformasional diantara berbagai jenis gaya kepemimpinan untuk perusahaaan sektor public dan swasta. Hasil analisis regresi dan korelasi menunjukkan bahwa gaya kepemimpinan transformasinal, transaksional dan laissez-faire mempunyai korelasi dengan kinerja karyawan, hanya korelasi gaya kepemimpinan transaksional dengan kinerja karyawan lebih lebih rendah dari transformasional. Sedangkan gaya kepemimpinan laissez-faire mempunyai hubungan ngatif dengan kinerja karyawan. Urutan kemampuan penjelas adalah gaya kepemimpinan transformasional 63,2\% (Adjusted $\mathrm{R}^{2}=0.632$ ), gaya kepemimpinan transaksional 55,1\% (Adjusted $\mathrm{R}^{2}=0.551$ ) dan gaya kepemimpinan laissez-faire $66,6 \%$ (Adjusted $\mathrm{R}^{2}=0.666$ ).

Penelitian yang dilakukan oleh Trottier, dkk (2008) berjudul Examining the Nature and Significance of Leadership in Government Organizations. Penelitian ini mengukur enam dimensi kepemimpinan transaksional dan transformasional (management by exception, contingen reward, individualized considertion, idealized influence, inspirational motivation, dan intellectual stimulation), dengan menggunakan 24 item pertanyaan yang diadaptasi dari LMQ. Hasil penelitian menunjukkan bahwa variasi efektivitas kepemimpinan yang dirasakan, yang dijelaskan oleh kepemimpinan transaksional sebesar $65 \%$ dan kepemimpinan transformasional $70,9 \%$. Sedangkan variasi efektivitas kepemimpinan yang dirasakan, yang dijelaskan oleh faktor kepemimpinan gabungan $70,5 \%$. Selain itu penelitian ini juga menemukan bahwa variasi kepuasan bawahan dijelaskan oleh kepemimpinan transaksional sebesar 70,7\%, dan transformasional 72,5\%. Sedangkan variasi kepuasan bawahan yang dijelaskan faktor kepemimpinan gabungan sebesar $72,1 \%$. Menyangkut pentingnya kepemimpinan transaksional dan transformasional dalam lingkungan pemerintahan, penelitian ini menemukan bahwa kepemimpinan transformasional memiliki peran besar dalam persepsi pegawai federal dibandingkan kepemimpinan transaksional. Namun, pegawai federal sebenarnya menilai pemimpin mereka lebih tinggi dalam faktor kepemimpinan transaksional $(3,47)$ dibandingkan faktor transformasional $(3,27)$.

Penelitian ini pada prinsipnya sama dengan penelitian-penelitian tersebut yakni menggunakan model kepemimpinan transaksionaal dan transformasional dalam memperediksi kinerja PNS di Kabupaten Alor, namun yang membedakan adalah bahwa model penelitiannya bersifat hubungan langsung (tanpa variabel antara).

Permasalahan pertama (point a) penelitian ini akan dianalisis secara deskriptif melalui komposisi rata-rata jawaban responden. Model kepemimpinan yang memperoleh rata-rata jawaban tertinggi mengindikasikan bahwa model kepemimpinan itu yang menonjol berlaku dalam birokrasi di Kabupaten Alor. Sedangkan permasalahan pada point $\mathrm{b}, \mathrm{c}$ dan $\mathrm{d}$ akan diuji melalui pembuktian hipotesis berikut :

H1 : Kepemimpinan transaksional berpengaruh signifikan terhadap kineja PNS.

$\mathrm{H} 2$ : Kepemimpinan transformasional berpengaruh signifikan terhadap kineja PNS

H3 : Kepemimpinan transaksional dan transformasional secara simultan berpengaruh signifikan terhadap kineja PNS. 


\section{Model Penelitian}

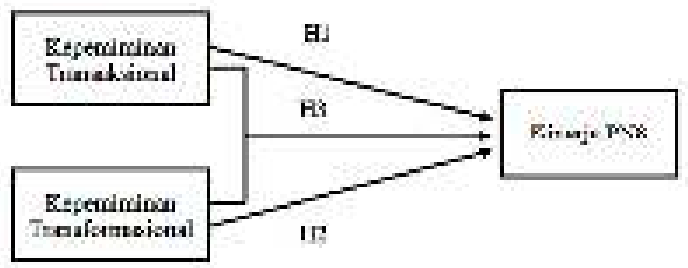

\section{E T O D E}

\section{Populasi dan Sampel.}

Populasi penelitian ini adalah seluruh Pegawai Negeri Sipil (PNS) yang bekerja di 11 Badan, 15 Dinas, 2 Kantor dan 4 Sekretariat dalam lingkup pemerintahan Kabupaten Alor. Sampel ditentukan sebagai berikut : Pertama, penentuan sampel Satuan Kerja Perangkat Daerah (SKPD). Pada tahap ini ditetapkan secara acak 3 Badan, 4 Dinas, 1 Kantor dan 1 Sekretariat sebagai sampel. Seluruh PNS pada Badan, Dinas, Kantor dan Sekretariat sampel merupkan populasi sasaran. Kedua, penentuan sampel PNS. Jumlah populasi sasaran pada Badan, Dinas, Kantor dan Sekretariat sampel sebanyak 389 orang. Merujuk pada tabel penentuan jumlah sampel yang dikembangkan oleh Isaac dan Michael (Sugiyono, 2004) dengan tingkat kesalahan 5\%, maka jumlah sampel untuk jumlah populasi tersebut adalah sebesar 182 orang. Jumlah sampel ini ditentukan secara acak terstratifikasi tidak proporsional (Sugiyono, 2004). Stratifikasi dilakukan berdasarkan posisi PNS dalam organisasi yakni (a) Pegawai yang menempati posisi puncak organisasi (kepala badan, dinas, kantor, sekretaris) dan pegawai yang menempati posisi kepala bagian/kepala bidang dalam struktur organisasi; (b) Pegawai yang menempati posisi kepala sub bagian/kepala seksi dalam struktur organisasi, dan (c) pegawai pelaksana/staf, yang berfungsi menangani tugas-tugas pelaksanaan.

Jumlah sampel masing-masing strata setiap Badan, Dinas, Kantor, dan Sekretariat sebagaimana pada kolom 4,6 , dan 8 pada tabel 1 ditentukan sebagai berikut :

1. Jumlah total populasi setiap strata pada kolom 3, 5, dan 7 dibagi dengan jumlah total populasi pada kolom 9, dikalikan dengan jumlah sampel yang ditentukan sebagai berikut :
a. Jumlah sampel Kepala/Sekretaris/ Kabid $=34 / 389 \times 182=15,90 \quad(16$ orang).
b. Jumlah sampel Kasub/Kasi = $88 / 389 \times 182=41,17=(41$ orang $)$.
c. Jumlah sampel staf $=267 / 389 \times 182=$ $124,92=(125$ orang $)$.

2. Jumlah pegawai setiap strata masingmasing Badan, Dinas, Kantor, dan Sekretariat dibagi dengan jumlah populasi masing-masing strata dikali dengan jumlah sampel masing-masing starata yang sudah dihitung pada langkah pertama sebagai berikut:

a. Jumlah sampel Kepala/Sekretaris/ Kabid untuk Badan Perencanaan Pembangunan Daerah: 5/34X16 orang $=2,35$ ( 2 orang)

b. Jumlah sampel Kasub/Kasi untuk Badan Perencanaan Pembangunan Daerah : $11 / 88 X 41$ orang $=5,12(5$ orang)

c. Jumlah sampel staf untuk Badan Perencanaan Pembangunan Daerah: $43 / 267 X 125$ orang $=20,13$ (20 orang).

Dengan teknik perhitungan yang sama, akan diktehaui jumlah sampel setiap strata untuk masing-masing Badan, Dinas, Kantor, dan Sekretariat sebagaimana pada tabel 1.

Tabel 1

Kerangka sampel penelitian

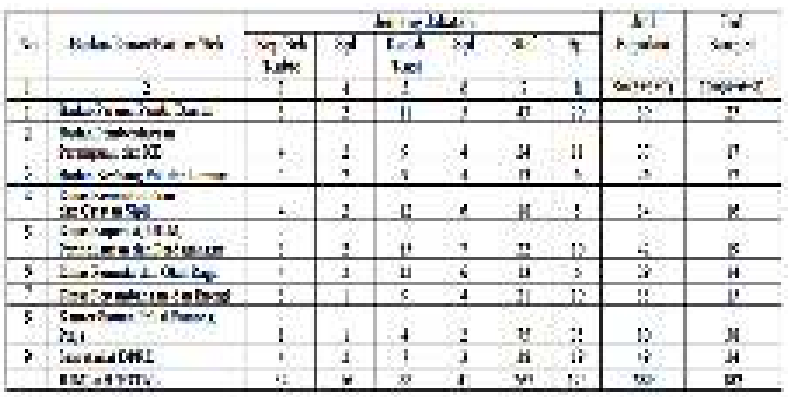

\section{Variabel Penelitian}

Variabel dalam penelitian terdiri dari variabel bebas: model kepemimpinan transaksional (X1), dan model kepemimpinan transformasional (X2) dan varabel terikat : kinerja pegawai negeri sipil (Y). Definis operasional, indikator dan skala setiap variabel pada tabel berikut.

Tabel 2

Variabel, Indikator, Instrumen dan Skala

\begin{tabular}{|c|c|c|c|c|}
\hline V.बन & TH: & Tolo. & bann & 32. \\
\hline 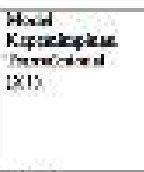 & 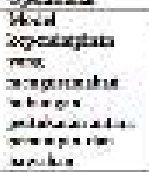 & 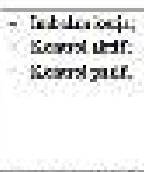 & $\begin{array}{l}\text { Motca } \\
\text { NStaxn }\end{array}$ & 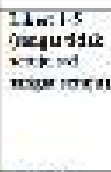 \\
\hline 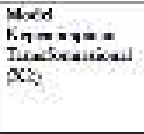 & 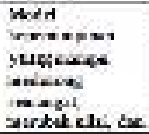 & 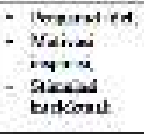 & $\begin{array}{l}\text { vormon } \\
\text { visen }\end{array}$ & 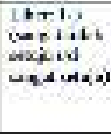 \\
\hline
\end{tabular}




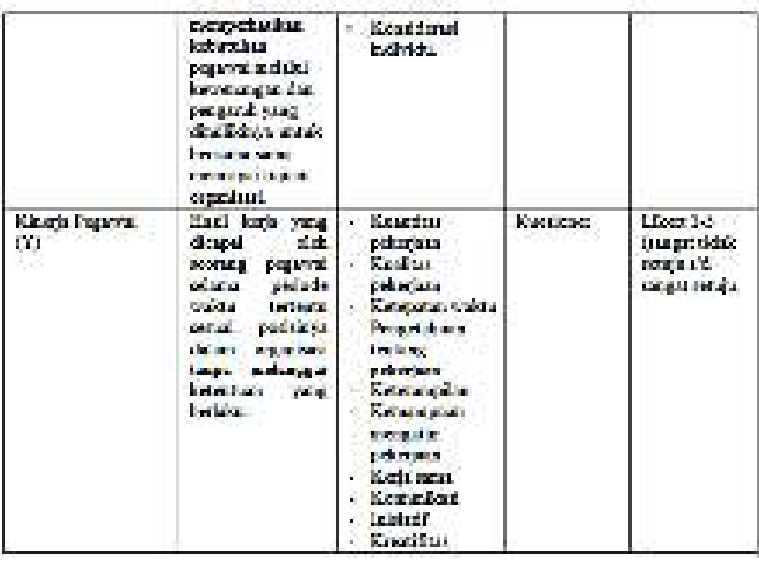

\section{Pengujian Instrumen}

Sebelum pengolahan data, akan dilakukan uji validitas dan reliabilitas instrumen. Validitas menunjukkan apakah instrumen yang ada mencerminkan variabel yang diukur. Dalam penelitian ini uji validitas dilakukan dengan mengkorelasikan skor setiap item dengan total skor. Teknik yang dipkai adalah teknik korelasi person product moment, dimana instrumen dikatakan valid apabila nilai koefisien korelasinya $(r)>r_{\text {tabel }}$.

Uji reliabilitas menunjukkan sejauh mana alat pengukuran dapat dipercaya atau dapat diandalkan konsistensinya dari waktu ke waktu. Dalam penelitian ini uji reliabilitas menggunakan teknik Alpha Cronbach, dimana instrumen dikatakan andal apabila memiliki koefisien keandalan (alpha) $\geq 0,6$.

\section{Analisis Data dan Uji Hipotesis}

Model yang dipakai dalam analisis data adalah model regresi berganda dengan persamaan : $\mathrm{Y}=\mathrm{a}+\mathrm{b} 1 \mathrm{X} 1+\mathrm{b} 2 \mathrm{X} 2+\mathrm{e}$, dimana:

$\mathrm{Y}=$ Kinerja PNS

$\mathrm{X} 1=$ Model kepemimpinan transaksional

$\mathrm{X} 2=$ Model kepemimpinan transformasional

a $=$ Konstanta

b1, b2 = Koefisien regresi variabel X1 dan X2

$\mathrm{e} \quad=$ error term

Uji hipotesis parsial menggunakan uji $\mathrm{t}$ dan simultan menggunakan uji F. Kedua uji dilakukan pada alfa $5 \%$ dengan ketentuan apabila nilai $\mathrm{t}$ dan nilai $\mathrm{F}$ sig lebih kecil dari alfa 5\% maka variabel bebas berpengaruh signifikan terhadap variabel terikat, dan jika yang terjadi sebaliknya maka variabel bebas tidak berpengaruh signifikan terhadap variabel terikat. Data penelitian diproses dengan bantuan program SPSS versi 19.
H A S I L

\section{Pengaruh Kepemimpinan Transaksional Terhdap Kinerja}

Hasil pengujian (lihat lampiran) memperlihatkan bahwa model kepemimpinan transaksional mempunyai $\mathrm{t}$ hitung sebesar 2,953 dan nilai sig t sebesar 0,004 . Nilai sig $t$ ini lebih besar dari alfa $5 \%(0,004>0,05)$. Ini berarti bahwa secara parsial kepemimpinan transaksional (X1) berpengaruh signifikan terhadap kinerja pegawai bila variabel lain konstan.

\section{Pengaruh Kepemimpinan Transformasional Terhdap Kinerja}

Hasil pengujian (lihat lampiran) menunjukkan bahwa kepemimpinan transformasional (X2) mempunyai t hitung sebesar 9,554 dan nilai sig $\mathrm{t}$ sebesar 0,000 . Nilai sig t ini lebih kecil dari nilai alfa $(0,000<$ 0,05). Dengan demikian dapat dikatakan bahwa secara parsial model kepemimpinan transformasional (X2) berpengaruh signifikan terhadap kinerja pegawai bila variabel lain konstan.

Selain itu, dari hasil analisis terlihat bahwa model kepemimpinan transformasional mempunyai pengaruh yang lebih besar terhadap kinerja pegawai daripada model kepemimpinan transaksional. Hal ini diindikasikan oleh koefisien regresi, dimana model kepemimpinan transformasional mempunyai koefisien regresi 0,554 lebih besar dari koefisien regresi model kepemimpinan transaksional yaitu 0,196.

Hasil penelitian tersebut berimplikasi teoritis dan praktis. Dari aspek teoritis, kepemimpinan transaksional yang berpengaruh lebih kecil terhadap kinerja pegawai merangsang kita untuk perlu melakukan studi lanjutan agar dapat diketahui konsistensi temuan tersebut diwaktu yang lain. Penelitian juga perlu dilakukan dalam tingkat birokrasi yang lebih luas, sehingga kecenderungan tersebut dapat digambarkan pada level birokrasi yang lain.

Pada tataran praktis, temuan tersebut memberikan gambaran bahwa model kepemimpinan birokrasi sedang berubah dan bergeser dari model kepemimpinan transaksional ke model kepemimpinan transformasional. Karena itu setiap pemimpin birokrasi harus menyadari sejak awal, model kepemimpinan transaksional pada suatu titik tertentu tidak bisa dipertahankan lagi. Sudah saatnya mereka harus lebih meningkatkan 
kepemimpinan transaformsional dalam mendorong dan memotivasi bawahan untuk mencapai kinerja yang diharapkan.

\section{Pengaruh Kepemimpinan Transaksional dan Transformasional Terhdap Kinerja.}

Hasil pengujian (lihat lampiran) memperlihatkan bahwa nilai $\mathrm{F}$ hitung sebesar 54,029 dan nilai sig $F \quad 0,000$. Nilai sig $F$ ini lebih kecil dari nilai alfa $5 \%(0,001<0,05)$. Ini berarti bahwa model kepemimpinan transaksional (X1) dan model kepemimpinan transformasional (X2) secara simultan berpengaruh signifikan terhadap kinerja pegawai. Besaran pengaruh kedua variabel tersebut adalah 0,376 atau $37,6 \%$ sebagaimana ditunjukkan oleh nilai koefisien determinasi ( $\mathrm{R}$ Squre). Besaran pengaruh ini juga menunjukkan bahwa variasi kinerja pegawai yang dapat dijelaskan oleh model kepemimpinan transaksional dan transformasional sebesar $37,6 \%$, sedangkan sisanya dijelaskan oleh variabel lain di luar variabel yang diteliti.

\section{I S K U S I}

Analisis regresi berguna untuk menguji hubungan kausalitas antara satu atau beberapa (variabel bebas) dengan variabel lainnya (variabel terikat). Dalam analisis kausalitas antara model kepemimpinan transaksional dan model kepemimpinan transformasional sebagai variabel bebas dengan kinerja pegawai sebagai varabel terikat ditemukan adanya hubungan positif dan sangat kuat. Keeratan hubungan kausal ini diindikasikan oleh koefisien korelasi (R) sebesar 0,614 . Hubungan positif ini bermakna semakin intensif penerapan model kepemimpinan transaksional dan transformasional akan semakin meningkatkan pula kinerja pegawai. Besaran keeratan hubungan ditandai oleh koefisien determinasi $\mathrm{R}^{2}$ 0,376. Artinya variasi kinerja pegawai dapat dijelaskan oleh model kepemimpinan transaksional dan transformasional sebesar 37,6\%.

Model kepemimpinan transaksional, berdasarkan analisis tabel distribusi frekuansi, diterapkan pada kategori tinggi (sering), sementara dari analisis nilai rata-rata, model kepemimpinan ini lebih menonjol dirasakan oleh para pegawai negeri sipil pada birokrasi di kabupaten Alor daripada kepemimpinan transformasional. Temuan ini searah dengan pandangan Weber (Bass, 1985) bahwa kepemimpinan birokrasi cenderung transaksional. Selain itu hasil uji signifikan menunjukkan bahwa

fe_manajemen@unmuh-kupang.ac.id model kepemimpinan transaksional berpengaruh signifikan terhadap kinerja pegawai. Meskipun demikian besaran pengaruh kepemimpinan transaksional terhadap kinerja lebih rendah dari model kepemimpinan transformasional. Besaran pengaruh kepemipinan transaksional hanya sebesar 0,196 daripada kepemimpinan transformasional sebesar 0,554 . Ini memberi kesan bahwa hasil penelitian ini tidak konsisten. Namun, jika di telaah, temuan ini didukung oleh studi yang dilakukan oleh Trottier dkk (2008) yang menemukan bahwa pegawai federal menilai pemimpin mereka lebih tinggi dalam faktor kepemimpinan transaksional dibandingkan faktor transformasional, tetapi variasi kepuasan yang dijelaskan oleh kepemimpinan transaksional lebih rendah dibandingkan dengan kepemimpinan transformasional. Studi lain yang mendukung hasil penelitian ini adalah studi Pradeep dan Prahu (2011) yang menyimpulkan bahwa korelasi kepemimpinan transaksional dengan kinerja karyawan lebih rendah dari kepemimpinan transformasional. Kerry Webb (2007) juga menyimpulkan bahwa variasi motivasi kerja karyawan yang dijelaskan oleh kepemimpinan transaksional lebih rendah dari kepemimpinan transformasional.

Model kepemimpinan transformasional, sesuai analisis distribusi frekuensi, diterapkan pada kategori sedang (kadang-kadang) dan tidak terlalu menonjol dirasakan oleh para pegawai sebagaimana hasil analisis nilai rata-rata. Namun bila dikaitkan dengan analisis signifikansi, model kepemimpinan ini mempunyai pengaruh yang signifikan terhadap kinerja pegawai, dan mempunyai pengaruh yang lebih besar daripada kepemimpinan transaksional. Hasil penelitian ini sejalan dengan studi Paracha, dkk (2012), Pradeep dan Prabhu (2011), Rowold (2009), Voon, dkk, (2011), Riaz dan Haider (2010).

Paparan di atas, dapat diringkas sebagaimana pada tabel 4.7. berikut.

Tabel 3

Ringkasan Temuan Penelitian

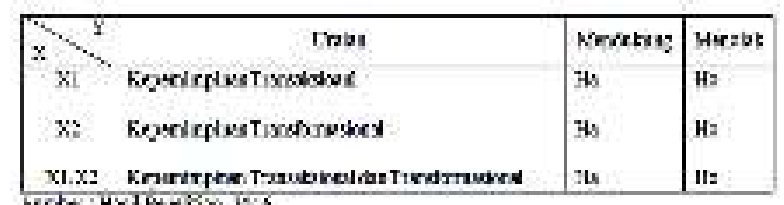

sede: HatFexing is:S

Temuan lain yang menarik adalah bahwa kepemimpinan transaksional dan transformasional diterapkan pada kategori yang berbeda. Kepemimpinan transaksional pada kategori tinggi (sering) sedangkan transformasional pada kategori sedang (kadang-kadang), yang berarti bahwa kedua model kepemimpinan ini diterapkan 
bergantian oleh pemimpin di birokrasi Kabupaten Alor secara belum berimbang. Kadang ia lebih menonjolkan model kepemimpinan transaksional tetapi kadang juga menggunakan model kepemimpinan transformasional secara moderat. Temuan ini sejalan dengan pandangan Bass (1995) bahwa kepemimpinan transaksional dan kepemimpinan transformasional tidak berakhir pada sebuah kontinum tunggal, tetapi lebih merupakan pola kepemimpinan dimana seorang pemimpin memiliki kedua pola ini, hanya menggunakannya dalam kadar yang berbeda. Untuk kinerja yang tinggi kepemimpinan transformasional diperlukan untuk meningkatkan perilaku kepemimpinan transaksional. Jadi untuk meningkatkan kinerja pegawai di pemerintahan Kabupaten Alor yang masih pada kategori sedang, diperlukan kepemimpinan transformsional.

Paparan temuan penelitian di atas, membawa implikasi teoritis dan praktis. Secara teoritis dapat dikatakan bahwa peran kepemimpinan transaksional sebagai penyumbang kinerja pegawai menunjukkan tendensi yang semakin kecil. Hal ini dapat dijadikan sebagai dasar untuk melakukan prediksi bahwa di masa yang akan datang, pandangan-pandangan yang mengatakan bahwa kepemimpinan birokrasi cenderung transaksional akan gugur. Di masa mendatang kepemimpinan transformasional akan lebih menonjol dalam kepemimpinan di lingkungan birokrasi. Untuk itu perlu penelitian lanjutan dalam substansi yang sama dan cakupan yang lebih luas dalam tingkatan birokrasi yang lain agar dapat diperoleh gambaran yang lebih konprehensif tentang perkembangan kontribusi peran variabel model kepemimpinan terhadap kinerja pegawai.

Secara praktis, temuan penelitian di atas merupakan signal bagi setiap pemimpin birokrasi bahwa mulai saat ini dan ke depan harus lebih meningatkan kadar kepemimpinan transformasional. Suatu model kepemimpinan yang mampu memotivasi dan menginspirasi para pegawai dalam meningkatkan kinerja mereka. Kecakapan sebagai pemimpin adalah hal penting, karena suatu organisasi itu akan berhasil atau bahkan gagal sebagian besar ditentukan oleh faktor kepemiminan. Pemimpin selalu menjadi fokus evaluasi mengenai penyebab keberhasilan atau kegagalan suatu organisasi (Thoha, 2010). Selanjunya penekanan pada model kepemimpinan transformasional untuk ditonjolkan dalam kepemimpinan birokrasi, karena model kepemimpinan ini mampu mendorong peningkatan kinerja pegawai sebagaimana hasil kajian berbebagai peneliti yang sudah dipaparkan sebelumnya. Di sisi lain model kepemimpinan transaksional lebih berorientasi pada politik kekuasaan, mengembangkan sistem nepotisme, tidak ada pemberdayaan pegawai, dan lain-lain yang berujung pada rendahnya kinerja aparat birokrasi (Anwaruddin, 2006).

\section{KETERBATASAN PENELITIAN}

Penelitian ini sudah diupayakan dilakukan secara sistematis dengan mengikuti kaidah-kaidah metodologi yang baku, namun disadari sepenuhnya bahwa masih terdapat berbagai kelemahan antara lain dapat diutarakan sebagai berikut (1) Instrumen penelitian dirancang dengan menggunakan skala Likert dengan lima pilihan jawaban persepsi yang bersifat self assessment. Hal ini sangat rentan terhadap kemungkinan terjadinya bias dalam jawaban responden, (2) Penggunaan analisis statistik, menyebabkan dinamika dan kompleksitas variabel belum sepenuhnya dapat diungkapkan dalam penelitian ini, dan (3) Penelitian ini masih terbatas pada variabel kepemimpinan, sehingga kinerja pegawai sepertinya "steril" dari pengaruh variabel-variabel lain baik yang ada di luar maupun dalam organisasi seperti kompensasi, lingkungan kerja, motivasi kerja, kepuasan kerja, teknologi, kebijakan-kebijakan pemerintahan pada level yang lebi tinggi dan lain-lain.

\section{SIMPULAN}

Dari temuan penelitian di atas, dapat disimpulkan (1) Kepemimpinan transaksional lebih menonjol dirasakan oleh pegawai negeri sipil di birokrasi Kabupaten Alor setelah lebih dari satu dasawarsa reformasi birokrasi digulirkan, (2) Kepemimpinan transaksional berpengaruh signifikan terhadap kierja pegawai di birokrasi Kabupaten Alor, (3) Kepemimpinan transformasional berpengaruh signifikan terhadap kinerja pegawai di birokrasi Kabupaten Alor, (4) Kepemimpinan transaksional dan transformasional secara bersama-sama berpengaruh signifikan terhadap kierja pegawai di di birokrasi Kabupaten Alor, (5) Kepemimpinan transformasional mempunyai pengaruh lebih besar terhadap kinerja pegawai di birokrasi Kabupaten Alor.

Untuk itu kepemimpinan transaksional sudah saatnya diimbangi dengan lebih menonjolkan kadar kepemimpinan transformasional, karena ke depan model kepemimpinan ini menjadi salah satu determinan utama kinerja pegawai dalam lingkungan birokrasi. Kepada pihak lain perlu melakukan 
penelitian lanjutan untuk memastikan konsistensi hasil penelitian ini di waktu yang lain dengan menggunakan pendekatan penelitian kualitatif dan juga menambahkan variabel lain agar dapat diketahui kinerja pegawai yang lebih mencerminkan beragam variabel.

\section{DAFTAR PUSTAKA}

Ababaneh Ismail Raed, 2010, The Role of Organizational Culture on Practising Quality Improvement in Jordanian Public Hospitals, Leadership in Health Sevices Vol 23 No.3, 2010.

Avolio, B. J., Zhu, W., Koh, W. L., \& Bhatia, P., 2004, Transformasional Leadership and Organizational Comitment; Mediating role of psycological empowerment and moderating role of structural distance, Organizational Behavior, 25, 951-968.

Bernandin H. John \& Joyce E.A. Russel, 1993, Human Resource Management, MacGraw-Hill, Inc. Singapore.

Burns, J. M., 1978, Leadership, New York : Harper \& Row.

Coberg, C. S. \& Cusmir, L. H., 1987, Orgnizational Culture Relationships with Creativity and Other Job-Related Variabels, Journal of Business Research 15, 397-409.

Dwiyanto, Agus, dkk, 2002, Reformasi Birokrasi Publik di Indonesia, Yogyakarta, Pusat tudi Kependudukan dan Kebijakan UGM.

Dessler Gary, 1997, Manajemen Sumber Daya Manusia, Jili 1 dan 2, Terjemahan Triana Iskandarsyah, PT Prenhallindo, Jakarta.

Furtwengler Dale, 2002, Penilaian Kinerja, Andi Yogyakarta.

Helriegel, D. \& Slocum, J., 2006, Organizational Behavior (11th Ed) Mason OH South Western.

Higgins Michael, 1984, Advantage and Limitation of ROI as Measure of Corporate Performance. Terjemahan Bambang Triono, PT Gramedia Jakarta.

Krishman, V. R., 2004, Impact of transformational leadership on followers' influence strategies, Leadership and Organization Development Journal, 25 (1), 58-72.

Kinerja Kabupaten/Kota di kawasan Timur Indonesia mengecewakan, Biak Rasine, 25 April 2011.

Kilmann, 1996, Beyond the Quicks Fix, Managing Five Tracks to Organisasional Success, Litton Educational Publishing, USA.
Mondy, Wayne R Siharplin Arthur \& Flipo Edwin B, 1995, Management : Concepts and Practices, Fourth Edition, Boston Allyn and Bacon, Inc.

Mitchel, T.R., Lason, J.R., 1987, People in organization, 3rd ed. New York: Mc Graw-Hill.

Odom Y Randall, dkk, 1990, Organizational Cultures, Commitment, Satisfaction and Cohesion, Public Productivity \& Management Review, Vol 14 No 2, pp 157-169.

PNS berkeliaran diberi sangsi, Pos Kupang, 25 Oktober 2012.

Pfeffer J. (1996), Competitive Advantage Through People, Harvard Business School Press.

Parry, K. W., 1998, Grounded Theory and Social Process : A new direction for leadership research, Leadership Quarterly, 9 85-105.

Pradeep Durga Devi dan Prabhu N.R.V., 2011. The Relationship between Effective Ledership and Employee Performance, IPCSIT vol 20 (2011) IACSIT Press, Songapore.

Ravianto J, 1986, Produktivitas dan Seni Usaha, Lembaga Sarana Informasi Usaha dan Produktivitas Jakarta.

Rivai Veithzal \& Sagala Jauvani Ella, 2009, Manajemen Sumber Daya Manusia Untuk Perusahaan Dari Teori ke Praktek, Edisi Kedua, Rajawali Pers.

Simic, I., 1998, Transformational Leadership : The key to successful management. Organizational Change, 1 (6), 49-55.

Suryanto, dkk., 2008, Kajian Pengukuran dan Evaluasi Kinerja Manajemen PNS di Daerah, Pusat Kajian Kinerja Otonomi Daerah Jl. Veteran no 10 Jakarta.

Sugiono, 2004, Metode Penelitian Bisnis, CV Alfabeta Bandung.

Trottier Tracey, dkk., 2008. Examining the Nature and Significance of Leadership in Government Organizations, Essay on Leadership in Organization, Public Administration Review, March/April 2008.

Webb Kerry, 2007, Motivating Peak Performance : Leadership Behavior That Stimulate Employee Motivation and Performance, Christian Higher Education, 6 : 53-71.

Wallach E, 1983, Individuals and Organization: the culture match, Training and Development Journal, Vol 12, pp 28-36. 